\title{
Somatic energy content and histological analysis of the gonads in Antarctic fish from the Scotia Arc*
}

\author{
FABIÁN ALBERTO VANELLA, JORGE CALVO, ELBA ROSA MORRICONI \\ and DANIEL RAMÓN AURELIANO
}

Centro Austral de Investigaciones Científicas, CONICET, Ushuaia, Argentina. E-mail: fvanella@tierradelfuego.org.ar

\begin{abstract}
SUMMARY: Histological characteristics of the gonads and the energy contents of axial muscle, liver and gonads of Antarctic notothenioid fish collected during the LAMPOS (Latin American Polarstern Study) survey in April 2002 were analysed. Ovaries and testes were staged following histological maturity criteria. Oocyte diameters frequency were established and fecundity values were estimated. The energetic values $(\mathrm{kJ} / \mathrm{g})$ of different organs were determined using a microcalorimetric bomb. Ovaries of Chaenocephalus aceratus showed a generalised atretic process. The gonadal histology of Champsocephalus gunnari, Pseudochaenichthys georgianus and Chionodracus rastrospinosus suggests that their spawnings take place in autumn. Gobionotothen gibberifrons and Lepidonotothen larseni females were in the process of maturation, with the ovaries of the former containing yolked and atretic oocytes together. Ovaries of Lepidonotothen kempi showed old postovulatory follicles, which provided evidence of previous spawning. Gonads from both sexes of Dissostichus eleginoides were immature. Absolute and relative fecundity were lower in Channichthyidae than in Nototheniidae. The energy contents of the different organs analysed were: liver $>$ gonads $>$ axial muscle. The highest energy density value (kJ/g wet body mass)
\end{abstract} was found in Dissostichus eleginoides.

Keywords: energy content, reproduction, gonadal histology, ovary, testis, Antarctic fish, notothenioids.

RESUMEN: CONTENIDO ENERGÉTICO SOMÁTICO Y ANÁLISIS HISTOLÓGICO GONADAL DE PECES ANTÁRTICOS DEL ARCO DE SCOTIA. - Se analizaron las características histológicas de las gónadas y los contenidos energéticos del músculo axial, hígado y gónadas de peces provenientes del crucero LAMPOS (Latin American Polarstern Study) realizado durante abril 2002. Los ovarios y testículos fueron clasificados en diferentes estadios de maduración siguiendo criterios histológicos, se establecieron las distribuciones de frecuencias de diámetros oocitarios y se estimaron los valores de fecundidad de los especímenes en avanzado estado de madurez. El contenido energético $(\mathrm{kJ} / \mathrm{g})$ fue determinado utilizando una microbomba calorimétrica. Los ovarios de Chaenocephalus aceratus presentaron un generalizado proceso de atresia oocitaria. La histología gonadal de Champsocephalus gunnari, Pseudochaenichthys georgianus y Chionodracus rastrospinosus sugiere que se produjo un desove al inicio del otoño antártico. Gobionotothen gibberifrons y Lepidonotothen larseni se encontraron en proceso de maduración, ovarios de la primera especie contuvieron oocitos vitelados y atrésicos simultáneamente. Los ovarios de Lepidonotothen kempi mostraron folículos postovulatorios viejos que evidencian un desove previo. Las gónadas de ambos sexos en Dissostichus eleginoides fueron inmaduras. Tanto la fecundidad absoluta como la relativa calculadas fueron menores en las especies de Channichthyidae que en las de Nototheniidae. En las diferentes especies estudiadas el contenido energético (kJ/g de peso seco libre de cenizas) del hígado alcanzó los valores más altos seguido por las gónadas y el músculo axial. Dissostichus eleginoides presentó los valores de densidad energética (kJ/g peso húmedo del cuerpo) más elevados.

Palabras clave: contenido energético, reproducción, histología gonadal, ovario, testículo, peces antárticos, nototénidos.

\section{INTRODUCTION}

In terms of species abundance and biomass, the sub-order Notothenioidei constitute the dominant

*Received July 27, 2004. Accepted June 8, 2005. fish group in the Southern Ocean (Eastman and Mc Cune, 2000). The suborder is thought to have evolved before the formation of the Antarctic Polar Front (APF), around 20 million years ago (Clarke and Johnston, 1996). Almost a hundred notothenioid species have an exclusively Antarctic distribution, 
whereas there are 26 non-Antarctic species (Eastman and Eakin, 2000; Montgomery and Clements, 2000). Evidence from molecular phylogenetic analysis suggests that some families, namely Bovichtidae, Pseudaphritidae and Eleginopidae, spread out of Antarctic waters before the establishment of the APF (Stankovic et al., 2002). Similar analyses suggest that the barrier of APF was permeated in some opportunities allowing a successful migration from the Antarctic and colonisation of Subantarctic waters (Bargelloni et al., 2000). The largely non-Antarctic genus Patagonotothen resulted especially successful, giving rise to 14 species (Eastman, 1995).

Information about reproductive features such as maturation and spawning schedule, fecundity or reproductive effort of Subantarctic species of notothenioids is available only for a few species. Therefore, comparative analyses between species with Antarctic and Subantarctic distributions are hampered.

The energetic demands for reproduction and growth are conditioned by food intake and the physiological reproductive strategies (Calow, 1985). Low temperatures and highly seasonal productivity of the Antarctic marine environment modulate the energy budget of Antarctic fish and the seasonality of spawning. Some species of Antarctic Notothenioidei, like Notothenia rossii, $N$. coriiceps and a great number of channichthyids, spawn a few thousand large yolky oocytes (more than $3 \mathrm{~mm}$ in diameter), usually during autumn, while other species of Nototheniidae spawn a greater number of small oocytes at any time of the year (Ekau, 1991; Kock and Wilhelms, 2003). Pseudochaenichthys georgianus and Champsocephalus gunnari require about one year to complete the yolk deposition, while Chaenocephalus aceratus and N. coriiceps need a longer time (Everson et al., 1996; Everson, 1994; Kock and Everson, 1997; Kock and Kellermann, 1991). To understand the gonadal cycle and yolk deposition process, a more intense sampling schedule throughout the year would be necessary.

The reproductive characteristics of fish from the Southern Ocean were studied in many species, in some of which histological gonadal descriptions were made (Eastman and DeVries, 2000; Everson et al., 1991; La Mesa et al., 2003; Macchi and BarreraOro, 1995; Russo et al., 2000; Shandikov and Faleeva, 1992; Van der Molen and Matallanas, 2003; see Kock and Kellerman, 1991 and references therein). Most studies on reproduction were carried out only in summer-autumn (Kock and Kellermann, 1991; Duhamel et al., 1993; Kock et al., 2000; Kock and Wilhelms, 2003) because that is the season when most of the Antarctic scientific cruises take place.

Different attempts to determine the energy budget of fish species of the Southern Ocean have been made in recent years. Food intake requirements and feeding energetics were analysed by Kock (1992) in several species of notothenioids, by Johnston and Battram (1993) in Notothenia neglecta and by Chekunova and Naumov (1982) in Notothenia rossi marmorata. The proximal biochemical compositions of $N$. r. marmorata and Lepidonotothen (=Notothenia $)$ gibberifrons were studied by Kozlov (1981; 1982). The lipid compositions of high Antarctic nototheniod fish were studied by Friederich and Hagen (1994), Hagen et al. (2000) and Kamler et al. (2001).

In the present study we analysed the reproductive characteristics of Antarctic Notothenioidei species, comparing fish samples from the northern and southern branches of the Scotia Arc. In addition, we analysed the energetic content in gonads, liver and muscle of Antarctic nototheniods for the first time.

\section{MATERIAL AND METHODS}

Fishes were collected during the LAMPOS survey in April 2002 (Fig. 1) and detailed cruise information has been published by Arntz and Brey (2003) for the total number of fishes caught during the cruise and the number considered for the various investigations in this paper (see Tables 1 and 2). Shipboard sampling involved taxonomic identification, labelling and measurement of total length (TL) and standard length (SL) to the nearest $\mathrm{cm}$ below. Total weight (TW), sex, and weight of liver, stomach and gonads were determined to the nearest $0.1 \mathrm{~g}$ below. Gonado-somatic index (GSI) was calculated as the percentage of gonadal weight per total body weight.

Gonad samples for histological studies were preserved in Bouin fixative, dehydrated and included in Paraplast. Histological sections (5 to $7 \mu \mathrm{m}$ thick) were stained with haematoxylin-eosin and Periodic Acid-Schiff-haematoxylin (PAS-H).

Absolute fecundity was estimated by extrapolating the number of oocytes of 3 weighed subsamples to the weight of the entire ovary. The number of oocytes produced per gram of total weight (relative fecundity) was also determined. A portion of ovary 


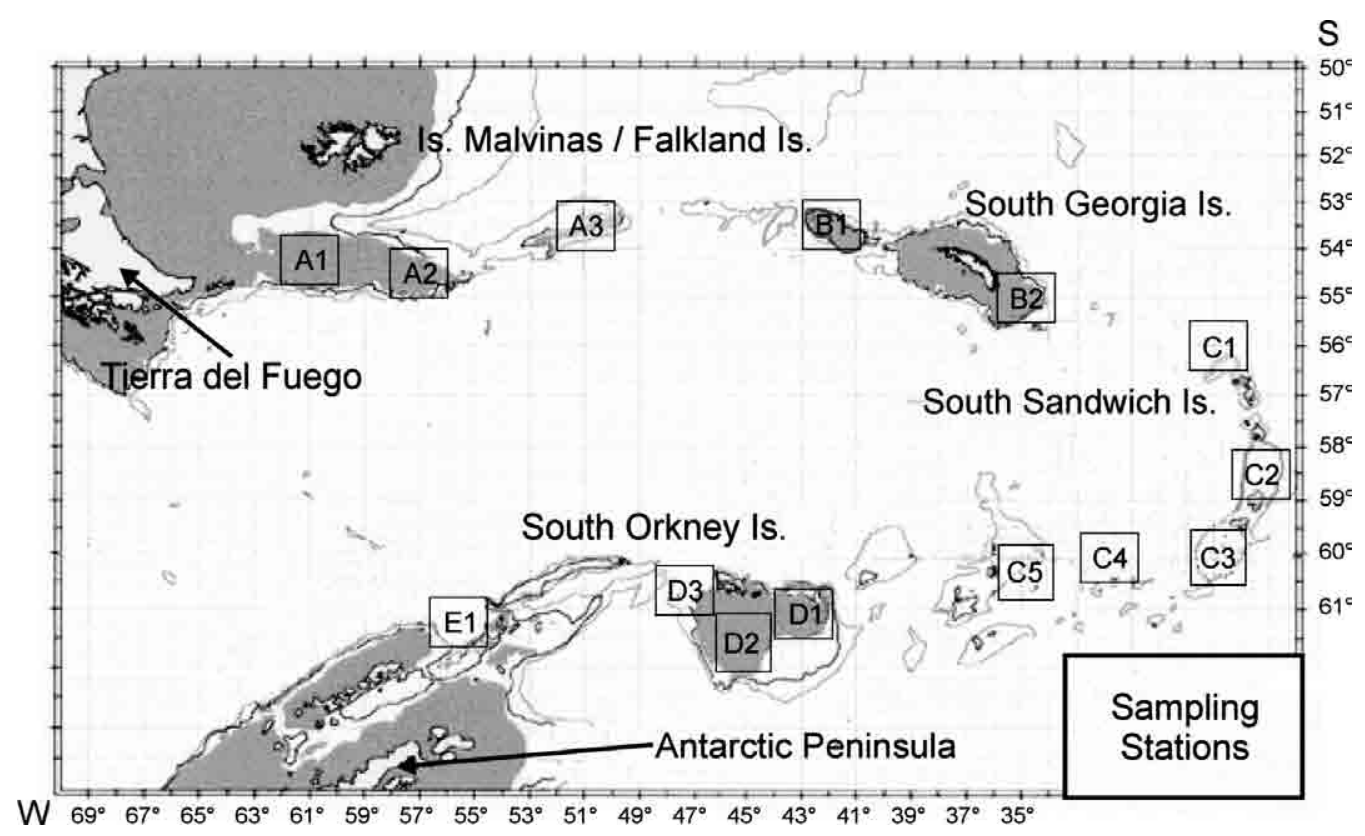

FIG. 1. - Sampling stations of the Latin American "Polarstern" Study

TABLE 1. - Oocyte diameter, absolute and relative (Oocytes/ TW) fecundity in Antarctic Notothenioidei (*no ripe oocytes).

\begin{tabular}{|c|c|c|c|c|c|c|}
\hline Species & $\mathrm{n}$ & $\begin{array}{c}\text { Oocyte } \\
\text { diameter }(\mu \mathrm{m})\end{array}$ & $\begin{array}{l}\text { Oocyte wet } \\
\text { weight (mg) }\end{array}$ & $\begin{array}{l}\text { Oocyte dry } \\
\text { weight (mg) }\end{array}$ & $\begin{array}{l}\text { Absolute } \\
\text { fecundity }\end{array}$ & $\begin{array}{l}\text { Relative } \\
\text { fecundity }\end{array}$ \\
\hline N. rossii & 1 & $2150-3150$ & 8.06 & 2.67 & 89793 & 27 \\
\hline C. gunnari & 4 & $1800-3100$ & 6.52 & 2.33 & 3933 & 14 \\
\hline C. rastrospinosus & 1 & $3900-4600$ & 30.24 & 8.41 & 4073 & 10 \\
\hline G. gibberifrons & 4 & $500-1200 *$ & 0.51 & 0.13 & 84067 & 103 \\
\hline P. georgianus & 2 & $3800-4700$ & 26.92 & 7.54 & 7317 & 9 \\
\hline L. kempi & 1 & $700-1200 *$ & 0.62 & 0.19 & 116420 & 175 \\
\hline
\end{tabular}

TABLE 2. - Relationship between total body weight (TW) / total body length (TL) and total energy content (TEC) / TL. Mean percentage water content (MWC \%). TEC for standardised fish at $40 \mathrm{~cm}$ TL (TEC $\left.{ }_{40}\right)$. Mean energy density $(\mathrm{ED} \pm \mathrm{SD}$ ) for each species analysed. $\mathrm{n}_{1}=$ total number of specimens caught in the LAMPOS survey; $\mathrm{n}_{2}=$ number of specimens used for energetic determination.

\begin{tabular}{|c|c|c|c|c|c|c|c|c|c|}
\hline Species & $\mathrm{n}_{1}$ & $\mathrm{TW}=\mathrm{a} \cdot \mathrm{TL}^{\mathrm{b}}$ & $r^{2}$ & $\mathrm{n}_{2}$ & $\mathrm{TEC}=\mathrm{a} \cdot \mathrm{TL}^{\mathrm{b}}$ & $\mathrm{r}^{2}$ & MWC \% & $\mathrm{TEC}_{40}$ & $\begin{array}{c}\text { Mean ED (SD)kJ g-1 } \\
\text { wet mass }\end{array}$ \\
\hline C. aceratus & 78 & $0.0010 \cdot \mathrm{LT}^{3.44}$ & 0.96 & 8 & $0.0043 \cdot \mathrm{TL}^{3.53}$ & 0.99 & 78.8 & 1944 & $5.38(0.45)$ \\
\hline C. gunnari & 76 & $0.0005 \cdot \mathrm{LT}^{3.76}$ & 0.95 & 5 & $0.4933 \cdot \mathrm{TL}^{2.28}$ & 0.47 & 76.8 & 2217 & $5.21(0.50)$ \\
\hline$P$. georgianus & 49 & $0.0008 \cdot$ LT $^{3.64}$ & 0.97 & 11 & $0.0003 \cdot \mathrm{TL}^{4.29}$ & 0.89 & 80.0 & 2238 & $4.55(0.41)$ \\
\hline C. rastrospinosus & 13 & $0.0040 \cdot$ LT $^{3.63}$ & 0.97 & 10 & $0.0040 \cdot \mathrm{TL}^{3.63}$ & 0.93 & 78.8 & 2615 & $4.99(0.24)$ \\
\hline G. gibberifrons & 92 & $0.0015 \cdot \mathrm{LT}^{3.52}$ & 0.97 & 14 & $0.0028 \cdot$ TL $^{3.78}$ & 0.98 & 76.9 & 3183 & $4.89(0.17)$ \\
\hline D. eleginoides & 38 & $0.0249 \cdot \mathrm{LT}^{2.71}$ & 0.95 & 5 & $0.2216 \cdot \mathrm{TL}^{2.70}$ & 0.88 & 68.7 & 4689 & $7.80(1.27)$ \\
\hline L. kempi & 158 & $0.0042 \cdot \mathrm{LT}^{3.42}$ & 0.99 & 8 & $0.0279 \cdot \mathrm{TL}^{3.38}$ & 0.97 & 75.5 & 7253 & $5.40(0.48)$ \\
\hline
\end{tabular}

was preserved in $10 \%$ formaldehyde to determine the frequency distribution of the oocyte diameters.

Samples of axial somatic muscle, liver and gonads were kept frozen $\left(-20^{\circ} \mathrm{C}\right)$ for energy studies. Wet mass of each sample was measured, and the material was dried at $60^{\circ} \mathrm{C}$ to constant weight and ground in a pestle mortar. Pellets (75-200 mg) were burned in a Parr 1425 micro-bomb calorimeter (Lucas, 1996). The values, corrected by ash and acid contents, were expressed as $\mathrm{kJ}^{-1}$ ash free dry weight (AFDW).

Total energy content was calculated as the sum of the energy content of gonads, liver, and muscle. Wet and dry weight values were used to calculate wet weight/dry weight conversions for energy determinations. The Friedman test was performed to compare the energy content between organs of each species (STATISTICA software). 

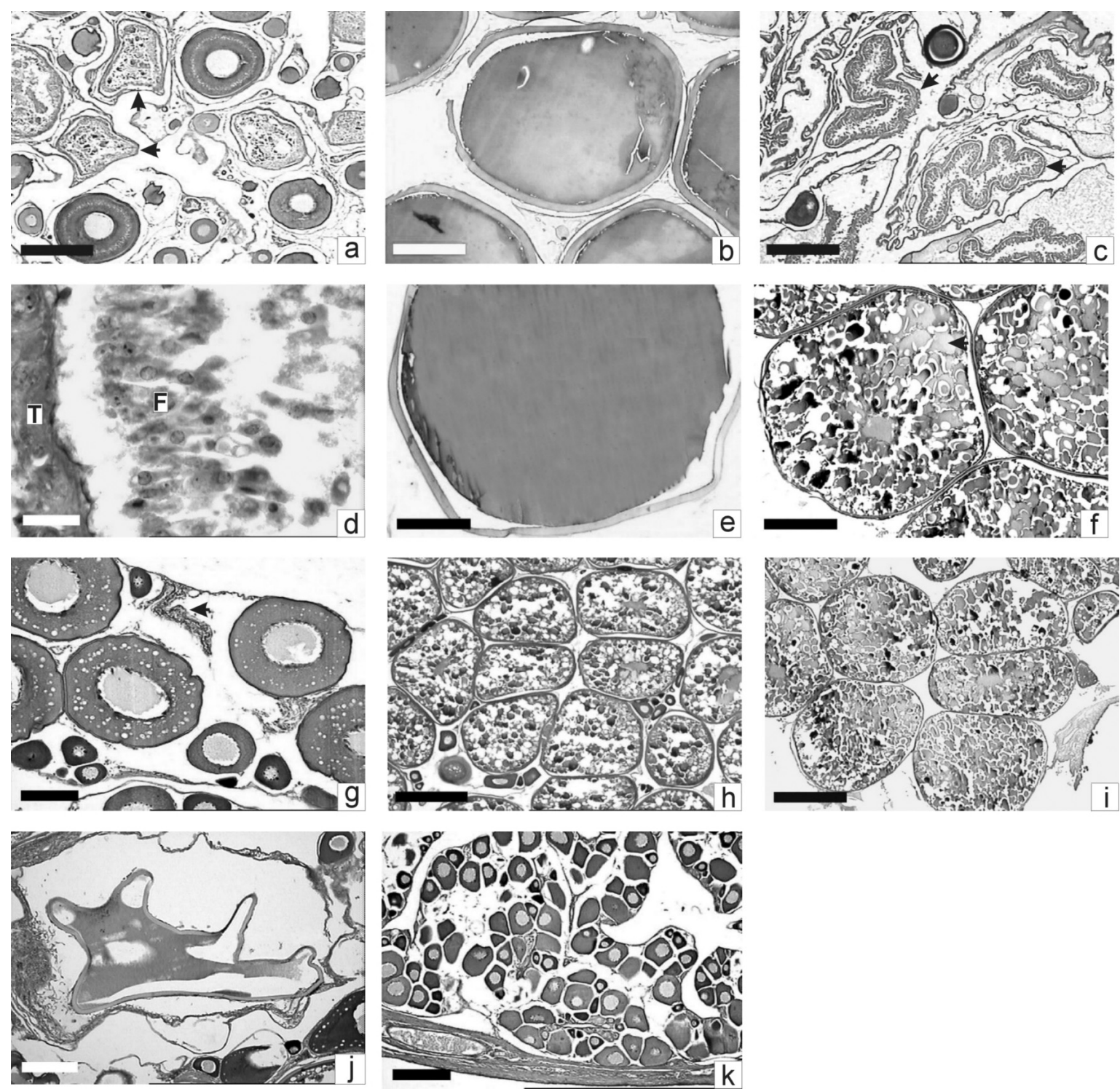

FIG. 2. - a: Chaenocephalus aceratus. Atretic oocytes (Arrows); b: Champsocephalus gunnari. Mature hyaline oocyte; c: Chionodraco rastrospinosus. Recent POF (Arrows); d: Chionodraco rastrospinosus. Recent POF. F: follicular cells. T: theca; e: Chionodraco rastrospinosus. Mature hyaline oocytes; f: Lepidonotothen larseni. Maturing oocytes with yolk globules starting the coalescence (Arrow); g: Lepidonotothen kempi. Previtellogenic oocytes and old POF (Arrow); h: Lepidonotothen kempi. Maturing oocytes with yolk globules; i: Gobionotothen gibberifrons. Maturing yolky oocytes; j: Gobionotothen gibberifrons. Residual mature oocyte; k: Dissostichus eleginoides. Basophilic oocytes. Scale bar represents: $500 \mu \mathrm{m}$ (a, b, c, g, h); $200 \mu \mathrm{m}$ (e, i, j); $100 \mu \mathrm{m}$ (f); $20 \mu \mathrm{m}$ (d). PAS - Haematoxylin.

\section{RESULTS}

\section{Gonad maturation}

\section{Chaenocephalus aceratus}

In the ovaries of Chaenocephalus aceratus (off South Georgia and South Orkney Islands) the vitellogenic oocytes showed different degrees of atresia (Fig. 2a). Some oocytes were starting the atretic process, with a fragmented chorion and hypertrophy of granulose cells. Other oocytes were already in an advanced stage of resorption, with a reduced cyto- plasm invaded by phagocytic cells distributed between yolk globules.

\section{Champsocephalus gunnari}

All the ovaries of Champsocephalus gunnari showed a bimodal oocyte diameter distribution (Fig. $3)$. The smaller oocytes $(<600 \mu \mathrm{m})$ had basophilic cytoplasm and primary yolk vesicles. The bigger oocytes (1600 to $3200 \mu \mathrm{m})$ were in an advanced stage of maturation, with homogeneous yolk stained heavily by PAS and eosin (Fig. $2 \mathrm{~b} ; \mathrm{GSI}=8$ ). Males had testes with wide central tubules full of sperm 
and the more external tubules containing isolated spermatogoniae placed against the tubule wall (Fig. $4 \mathrm{a}, \mathrm{GSI}=2.5$ ).

\section{Pseudochaenichthys georgianus}

Samples of Pseudochaenichthys georgianus were composed of both juvenile and sexually mature adult individuals. Ovaries of the former contained only basophilic or previtellogenic oocytes, while the latter had ovaries with mature oocytes (3800 to 4800 $\mu \mathrm{m}$, Fig. 3; GSI = 18). Sampled males were all mature. Their testes had tubules with numerous spermatogonia and a small amount of cysts containing spermatocytes (Fig. 4b; GSI = 2.02). Abundant spermatozoa, both in cysts and free, were observed in the central ducts. The irregular arrangement of spermatozoa and the phagocytic cells found between them suggested a previous evacuation.

\section{Chionodraco rastrospinosus}

Two types of ovaries were distinguished in this species. One type had scanty oocytes, with few yolk globules and recent post-ovulatory follicles (POF, Fig. 2c; GSI= 2.54). The POF were large, with a wide central lumen, and consisted of hypertrophied follicular cells arranged in an irregular convoluted structure (Fig. 2d). A monolayer theca with abundant small blood vessels and connective fibres surrounded the POF. The other type contained mature oocytes with homogeneous yolk (Fig. 2e; GSI= 22.49) and a batch of previtellogenic oocytes. This second type of ovary showed a bimodal distribution of oocyte diameters with a batch larger then $700 \mu \mathrm{m}$ and a batch of mature oocytes between 3900 and $4600 \mu \mathrm{m}$ (Fig. 3). In all sampled males the central testis tubules contained free spermatozoa while the peripheral tubules contained a small number of residual spermatozoa (Fig. 4c; GSI $=1.33$ ). Occasionally, phagocytic cells were present among the residual spermatozoa. Isolated spermatogoniae (about $12 \mu \mathrm{m}$ ) were distributed along the tubule walls and groups of them were close to the blind end of the tubules. The general histology of the testes suggested a recent evacuation of sperm.

\section{Lepidonotothen larseni}

The ovaries had oocytes with numerous secondary yolk globules. Some of them were starting the process of yolk coalescence (Fig. 2f; GSI = 5.15).

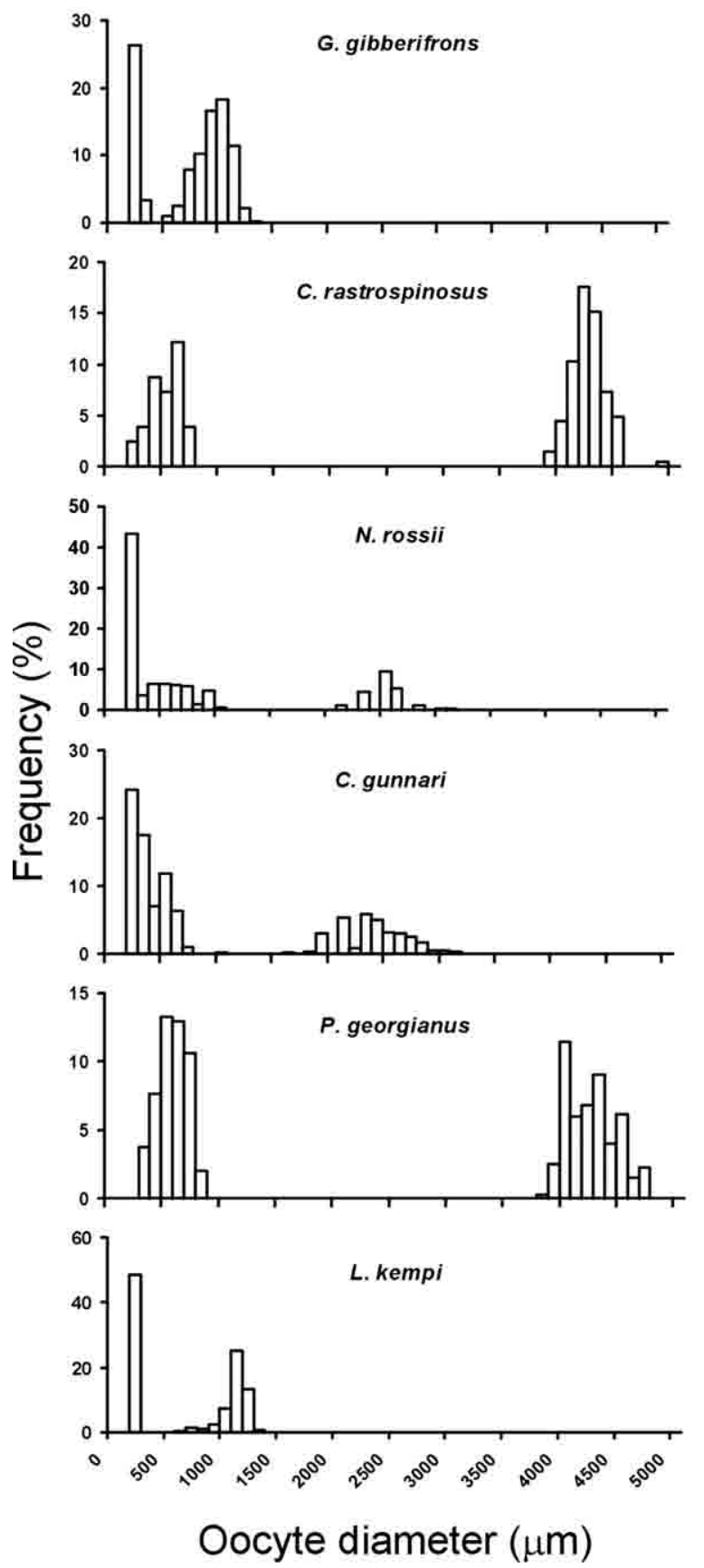

FIG. 3. - Size-frequency distribution of oocytes in each species: a) Gobionotothen gibberifrons $(\mathrm{n}=1774)$; b) Chionodraco rastrospinosus $(\mathrm{n}=205)$; c) Notothenia rossii $(\mathrm{n}=1165)$; d) Champsocephalus gunnari $(\mathrm{n}=2075)$; e) Pseudochaenichthys georgianus. $(\mathrm{n}=607) ; \mathrm{f})$ Lepidonotothen kempi $(\mathrm{n}=705)$.

\section{Lepidonotothen kempi}

Two ovary categories were found in the samples of this species. One type (fish captured especially at station C2, near the South Sandwich Islands), with GSI lower than 2, contained advanced (old) POF, oocytes in primary vitellogenesis and some residual oocytes in the process of resorption (Fig. 2g; GSI = 1.7). 

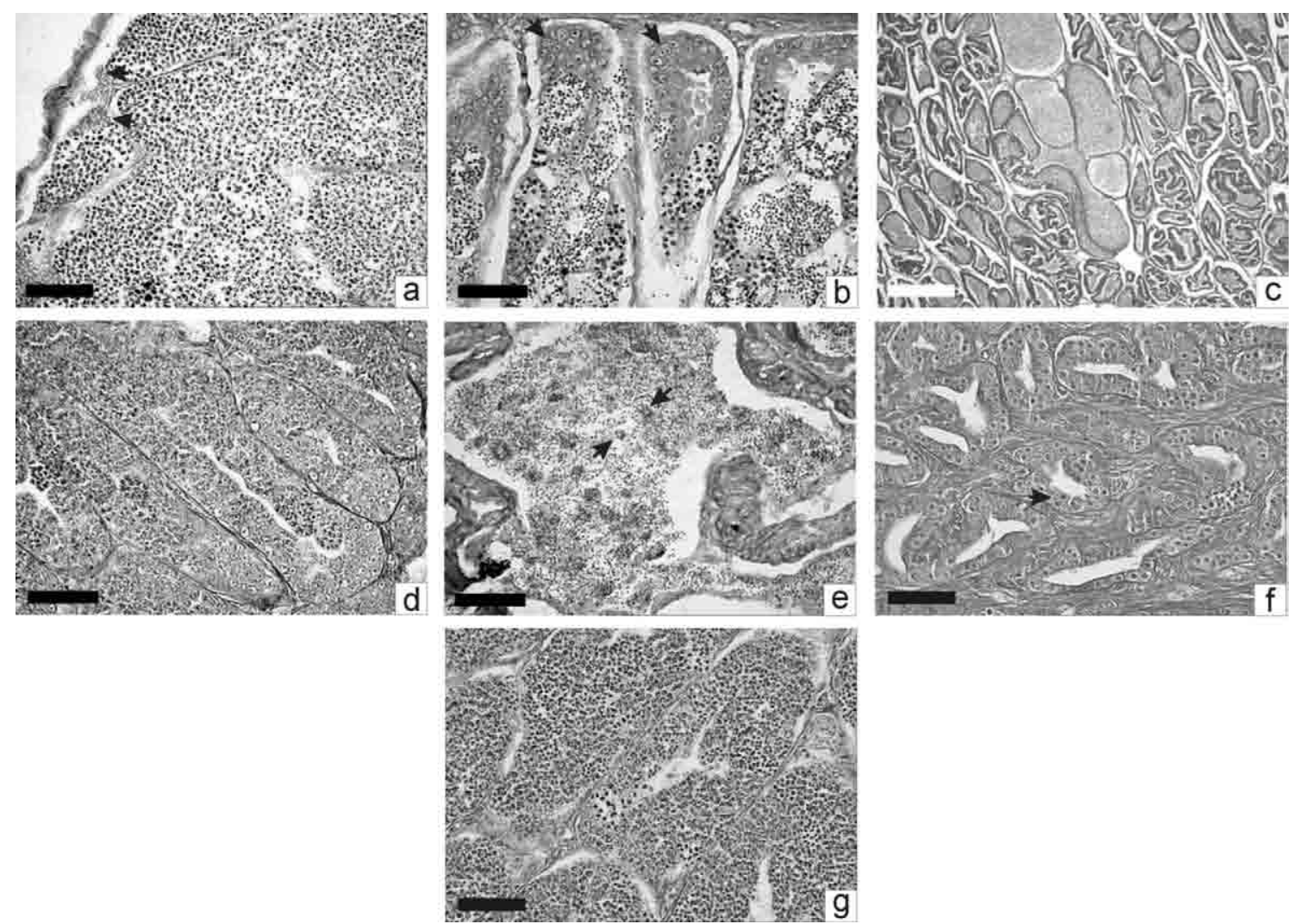

FIG. 4. - a: Champsocephalus gunnari. Isolated spermatogoniae (arrows). Abundant spermatozoa in the tubules; b: Pseudochaenichthys georgianus. Blind end of tubules with spermatogoniae (arrows), cysts of spermatocytes; c: Chionodraco rastrospinosus. Central ducts with free spermatozoa and shrunken peripherical tubules with residual sperm; d: Lepidonotothen kempi. Peripherical tubules with spermatogonia in cysts or isolated (arrow) and spermatocytes; e: Lepidonotothen kempi. Spermatozoa free in the lumina of the ducts with phagocytes (Arrow) between them; f: Dissostichus eleginoides. Tubules with spermatogoniae. A mitotic division is shown (arrow); g: Dissostichus eleginoides.

Cysts with spermatogoniae and spermatocytes. Scale bar represents: $50 \mu \mathrm{m}$ (a, b, d, e, f, g); $200 \mu \mathrm{m}$ (c). PAS - Haematoxylin.

The other group of ovaries (most of the fish captured at station C5) showed GSI between 3 and 10, and contained a batch of oocytes in secondary vitellogenesis (Fig. 2h; GSI = 7.2). The diameter distribution of oocytes in smears showed a bimodal distribution with $50 \%$ of basophilic oocytes $(300 \mu \mathrm{m})$ and $50 \%$ of maturing oocytes (500 - $1300 \mu \mathrm{m}$, Fig. 3).

Two different degrees of maturation were found in males of Lepidonotothen kempi. One group showed testes with active spermatogenesis, containing a large number of cysts of spermatogonia and spermatocytes arranged close to the tubule walls (Fig. 4d). A second group had scarce spermatogoniae, spermatozoa free in the lumina of the ducts and phagocytes between the spermatozoa (Fig. 4e), suggesting a previous sperm evacuation.

\section{Gobionotothen gibberifrons}

Ovaries of this species contained basophilic, previtellogenic and yolky oocytes (Fig. 2i). The ovaries from the fish sampled off South Georgia (B2 Sta- tion, Fig. 1) showed a lower degree of maturation $(\mathrm{GSI}=1.4)$ than the ovaries from the fish sampled off Elephant Island (E1 Station, Fig. 1; GSI =5.9). In histological sections the oocytes from fish sampled off South Georgia had a diameter of about $700 \mu \mathrm{m}$, while in the ones from off Elephant Island the diameter was around $880 \mu \mathrm{m}$.

In smears, a bimodal distribution of oocytes was found, with previtellogenic ones of less than $500 \mu \mathrm{m}$ diameter and yolky ones between 500 and $1300 \mu \mathrm{m}$ in diameter (Fig. 3).

Residual mature oocytes, which appeared to be a remainder from a previous spawning, were found in ovaries from fish sampled off Elephant Island (Fig $2 \mathrm{j})$. Testes were in the process of maturation, containing cysts of spermatocytes.

\section{Dissostichus eleginoides}

The total length of the specimens (53 to $93 \mathrm{~cm}$ ) was smaller than or close to the first maturation size (Everson and Murray 1999). Ovaries had basophilic 


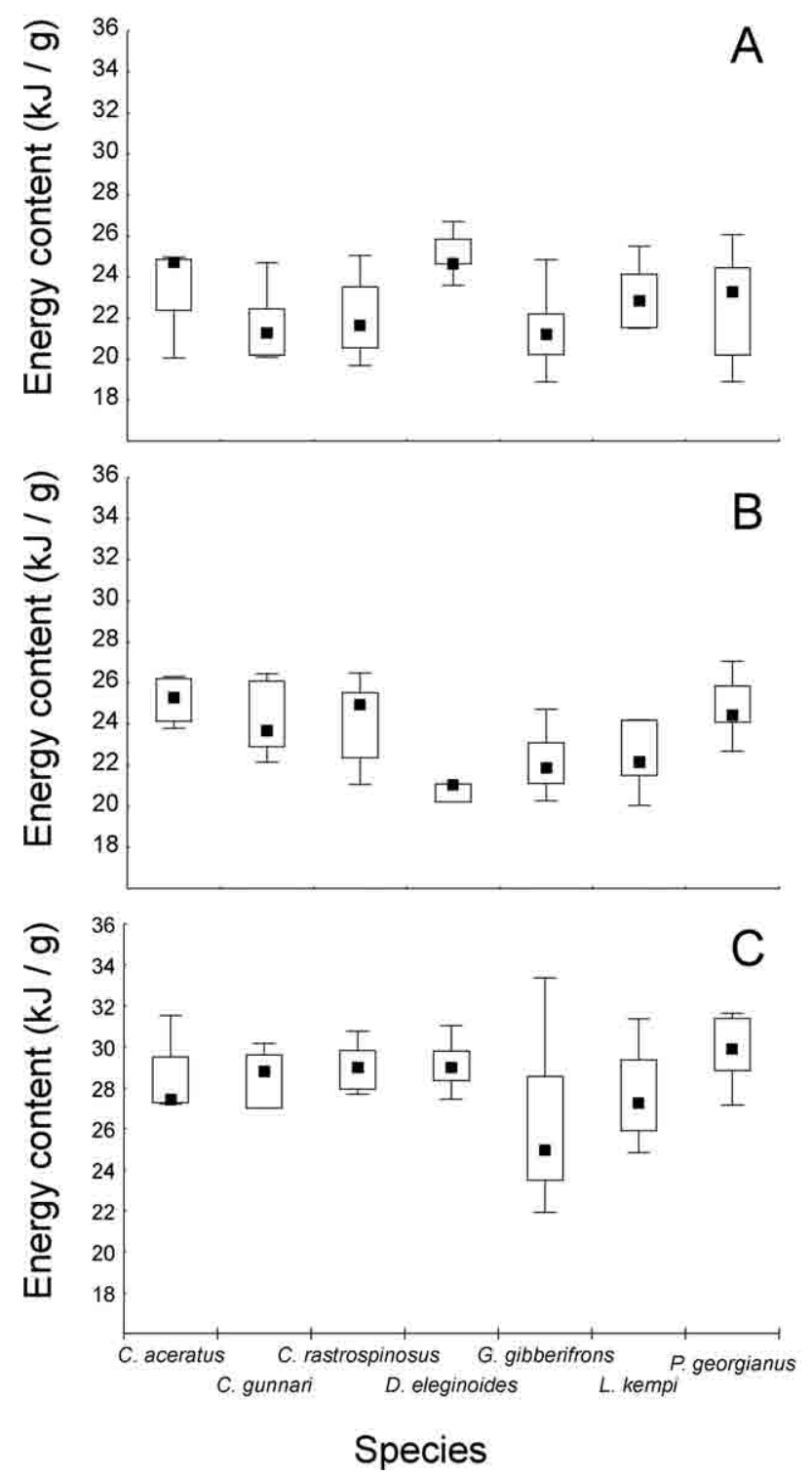

FIG. 5. - Energy content of different organs and tissues $(\mathrm{kJ} / \mathrm{g}$; ash free dry weight). Median. Box: $25-75 \%$. Whiskers: min-max. A: axial muscle; B: gonad; C: liver.

and previtellogenic oocytes filling the ovigerous lamellae (Fig. 2k). Two types of testes were found, one of them containing exclusively spermatogoniae covering the tubule wall (Fig. 4f, GSI $=0.02$ ) and the other one containing cysts with spermatogonia and spermatocytes (Fig. 4g, GSI= 3.2). There was a lumen in the centre of each tubule. Spermatozoa were not found in cysts or in tubules.

\section{Notothenia rossii}

Only one female specimen was captured, with its ovary in maturation. In smears almost $45 \%$ of the oocytes were previtellogenic opaque oocytes (300 $\mu \mathrm{m}$ diameter), while small diameter oocytes (400 to $1000 \mu \mathrm{m}$.) containing globular yolk reached about $35 \%$. The larger translucent yolky eggs had diameters between 2100 and $3200 \mu \mathrm{m}$ (Fig. 3).

\section{Fecundity}

The number of oocytes contained in the ovary was estimated in three species of Channichthyidae and in three species of Nototheniidae (Table 1). The only species with ovaries containing fully mature oocytes were $N$. rossii, $C$. rastrospinosus and $C$. gunnari. In the other species used for the estimation, the larger oocytes were in an advanced stage of vitellogenesis. Absolute and relative fecundity were lower in the Channichthyidae than in the Nototheniidae.

\section{Energy content}

Due to the small number of specimens studied in each species, the energy content $(\mathrm{kJ} / \mathrm{g})$ of both sexes was analysed together. The energy content of muscle and gonads only showed significant differences in D. eleginoides and C. rastrospinosus (Fig. 5A and B). The former had higher energy content in the muscle than in the gonads. Conversely, the latter had higher energy content in the gonads than in the muscle. The energy content of the liver was higher than the energy content of the gonads in all species $(\mathrm{p}<0.001)$, except in C. gunnari.

The energy content of the liver of G. gibberifrons (Fig. 6) was significantly higher in individuals sampled off South Georgia than in individuals sampled off Elephant Island (stations B2 and E1 respectively; Fig. 1).

The total energy content, size and mass for each species are shown in Table 2. Total energy content

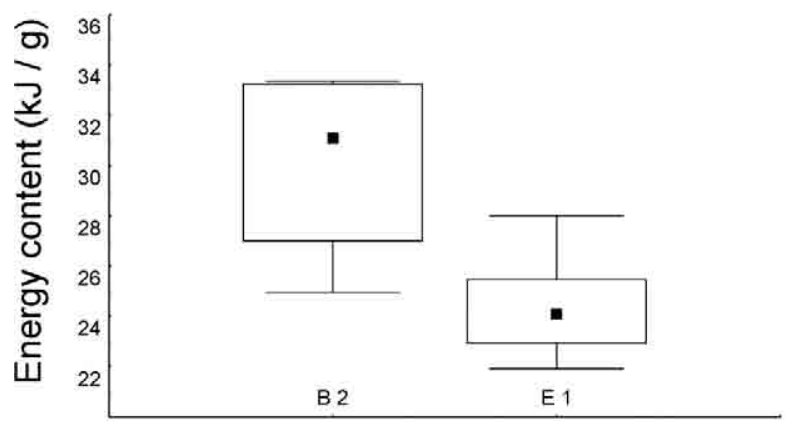

Station

FIG. 6. - Energy content in liver of G. gibberifrons captured on opposite sides of the Polar Front (kJ/g; ash free dry weight). Median. Box: 25-75\%. Whiskers: min-max. 
calculated for a standard specimen $(40 \mathrm{~cm}$ TL) was lower in channichthyids than nototheniids. The highest value was measured in L. kempi. Minimum and maximum values of energy density (ED kJ/g wet mass) were found in C. aceratus and D. eleginoides respectively.

\section{DISCUSSION}

The scarcity of material sampled from different species at the stations covered does not allow for generalisations about reproductive patterns and energetic characteristics of notothenioids along the Scotia Arc. However, the data are sufficient to perform an analysis in nine fish species caught mainly off South Georgia and in the southern branch of the Scotia Arc.

Biogeographically, our sampling sites are located in the ichthyofaunistic subregion of the Seasonal Pack Ice Zone and northern islands in which the Scotia Arc is included (sensu Kock, 1992). This is dominated by notothenioids of the genera Notothenia and Lepidonotothen, harpagiferids and channichthyids. Six of the species analysed in this study (Tables 1 and 2) were described as inhabiting exclusively this subregion. The other three species studied show a wider distribution. Chionodraco rastrospinosus inhabits both low and high Antarctic zones (Kock and Stransky, 2000); Lepidonotothen kempi (=L. macrophtalma + L. squamifroms, Schneppenheim et al., 1994, Eastman and Eakin, 2000) occurs in the low Antarctic zone and on the Patagonian shelf (Kock and Stransky, 2000); and Dissostichus eleginoides has a wide latitudinal distribution related to Subantarctic deep waters (as far as $35^{\circ} \mathrm{S}$, off southern Peru in the Pacific Ocean, and off Uruguay in the Atlantic Ocean; De Witt et al., 1990).

Christiansen et al. (1998) found differences in the reproductive timing between low and high Antarctic species, and considered that they were caused by both geographical gradients and different modes of spawning. In the present study, two principal reproductive groups were recognised in agreement with Christiansen et al. (1998): substrate spawning fish, with low fecundity, demersal oocytes of great diameter with a high energetic content (most of channichthyids), and pelagic spawners with numerous small-diameter oocytes (notothenioids and C. gunnari).

The values of relative and absolute fecundity found in this study (Table 1) are in agreement with the range of the values found in previous studies (Christiansen et al., 1998; Kock, 1989; Kock and Kellermann, 1991; Kock and Everson, 1997; Permitin, 1973). Although the mature females were few in number, our results help to understand the reproductive patterns of Antarctic notothenioids. They are characterised by delayed gonadal maturation, prolonged gametogenesis, usually one unique spawning per year and moderately high fecundity (North and White, 1987; Kock, 1992). Accordingly, most of the species analysed in the present study showed synchronous oocyte growth, with only one generation of maturing oocytes indicating that spawning occurred only once in each spawning season.

In all specimens of $C$. aceratus captured near both the South Orkney and South Georgia islands (Stations B2 and D2 respectively, Fig. 1), yolky oocytes of up to $1500 \mu \mathrm{m}$ diameter were found in atretic condition (Fig. 2a). The presence of atretic oocytes and the small size of healthy oocytes (1 $\mathrm{mm}$ ) suggest that these fish neither had spawned recently nor were prepared to spawn given the proximity of the spawning season (March - May, c.f. Permitin 1973; Kock, 1989). This generalised atretic phenomenon is considered as a failure in the attainment of final oocyte maturation that could be caused by the poor physical condition of the females, probably due to food shortage (Hunter and Macewicz, 1985; Yoneda et al., 2002). In the case of this species, food should be available all year round because adult specimens are considered opportunistic predators (Everson et al., 2000). The main cause of massive ovarian atresia in all sampled female specimens is not clear. Nevertheless, skipping spawning, when environmental conditions are unsuitable, could be a way to maintain somatic viability (McEvoy and McEvoy, 1992). When one species shows massive ovarian atresia and the reproductive cycle is studied using only macroscopic staging of ovaries without histological support, the risk of confusion between pre-reproductive atresia and the normal maturation process is high because the atretic oocytes can be misidentified as maturing ones (La Mesa et al., 2003).

Ovaries of C. gunnari captured off the South Orkneys (Station D2) contained mature oocytes with homogeneous yolk, with a diameter of about $3.2 \mathrm{~mm}$. The advanced stage of maturation of the ovaries and the testes full of mature sperm ready to evacuate found in the present study suggest the proximity of the spawning season in March-May, in agreement with Kock (1989). The ovaries analysed 
were healthy and showed no signs of an atretic process. Pre-reproductive regression was described in different opportunities for C. gunnari off South Georgia (Everson et al., 1991; Macchi and BarreraOro, 1995). These authors established a relation between the failure in ovarian maturation and the interannual variation in krill availability, the main food source for this species. Kock and Kellermann (1991) postulated that part of the population of $C$. gunnari in the Atlantic sector of the Southern Ocean does not spawn every year. The annual variability of individuals participating in spawning emphasises the importance of checking the actual percentage of spawning individuals every year in species under exploitation.

The coexistence of mature males and females of P. georgianus with oocytes around $4500 \mu \mathrm{m}$ in the South Georgia samples indicates the occurrence of spawning during April in agreement with Kock's and Kellermann's (1991) findings.

In $C$. rastrospinosus ovaries with either mature oocytes or recent POF (Fig. 2c-e) were found off South Georgia (Station B2). The histology of the testes showed sperm evacuation. These data are in agreement with the data of Kock (1989) and Kock and Kellermann (1991), who described the spawning of this species taking place in April around Elephant Island. These results suggest that spawning occurs simultaneously in an extensive area at both sides of the Antarctic Polar Front.

Female L. larseni (off Elephant Island, Station E1) had ovaries containing oocytes with numerous secondary yolk globules beginning the yolk coalescence process (Fig. 2f). This ovarian histology suggests that this species probably spawns in early winter, in agreement with the results of Kock (1989).

In L. kempi, the presence of two kinds of ovaries and testes (spent and maturing) indicates that spawning had occurred previously near the South Sandwich Islands (Fig. 1, Station C2, 254-262 m deep) since a maturing process with heavier ovaries containing yolked oocytes took place in deeper waters (Fig. 1, Station C5, 380-390 m deep). Our samples containing yolky oocytes in April suggest a protracted maturation during winter and spring. The presence of old POF in April (Fig. 2g) indicates either that the POF remained in the ovary as long as four months, or that the spawning off the South Sandwich Island occurred near the end of summer. If this was the case, spawning could occur later than November-December, as was described by Kock and Kellermann (1991) off the South Orkney Islands.
In April ovaries of G. gibberifrons were in the process of maturation. The yolky oocytes had not yet reached their maximum diameter (Fig. 3), which Kock (1989) determined at $2.5 \mathrm{~mm}$. The presence of mature residual oocytes in the ovaries collected in April (Fig. 2j) could indicate the occurrence of a slow process of resorption, since the anterior spawning period should have been in the previous winter, according to Kock (1989) for the population at Elephant Island. Testes in our samples contained only spermatocytes and not spermatozoa, suggesting that males were in the early process of maturation as well.

Female D. eleginoides were immature, probably because they had not reached the size of first maturity yet $(98.2 \mathrm{~cm}$ for females, Everson and Murray, 1999). One group of males was smaller than the size of first maturity $(78.5 \mathrm{~cm}$, Everson and Murray, 1999), and accordingly the testes were immature. A second group, composed of bigger males, was in the process of maturation (Fig. 4g), suggesting that these specimens could be ready to evacuate during the next spawning season, which Kock and Kellerman (1991) established as July-September.

Comparisons of reproductive features between the Antarctic and Subantarctic notothenioids are difficult because available data concerning the latter group are restricted to a few species, usually inhabiting shallow waters and without closely related species in the Antarctic zone. There are two exceptions: the genera Harpagifer and Champsocephalus. The first comprises several species in coastal waters of different peri-Antarctic islands ( $H$. bispinis, $H$. georgianus georgianus, H. georgianus palliolatus, $H$. kerguelenensis, H. spinosus) and one Antarctic species (H. antarcticus) (Fischer and Hureau, 1985). Reproductive characteristics were studied only in $H$. antarcticus (Daniels, 1978; White and Burren, 1992). The genus Champsocephalus has the nonAntarctic species C. esox, confined to the Magellan Province, whose reproductive biology was studied in a population inhabiting the Beagle Channel (Calvo et al., 1999). Sexually mature males are found from January to September, and females containing 3300 to 8600 mature oocytes or POF are found from February to November.

Individuals of the non-Antarctic species Patagonotothen tesellata spawn twice a year, in winter and at the end of summer. Each male guards egg masses spawned by several females in nests under flat rocks in lower levels of the intertidal zone of the Beagle Channel. Female P. tessellata spawn 
$7600-62,000$ oocytes with a diameter of 1000 to $1500 \mu \mathrm{m}$ (Rae and Calvo, 1995; 1996). P. cornuco$l a$ has not specifically been studied but preliminary observations indicate a similar timing of spawning (unpubl. observ.).

The non-Antarctic notothenioids show the only verified protandric hermaphroditic species that inhabits the Magellan region, Eleginops maclovinus (Calvo et al., 1992). This species spawns partially in June in central to southern Chile (Panozo, 1996), and shows a protracted spawning season between September and December around the Islas Malvinas/Falkland Islands in waters of 30-100 metres depth. Each batch comprises between 1.1 and 7.3 million oocytes with a diameter of 1 to $1.2 \mathrm{~mm}$ (Brickle et al., 2005). Hence, taking into account the extended spawning period and the possible repetitive spawning of the non-Antarctic notothenioids vs. the usual single spawning of Antarctic notothenioids, Subantarctic waters obviously impose less severe constraints on the reproductive effort than Antarctic waters.

The axial swimming muscles of fish represent more than $60 \%$ of their total body mass (Johnston, 2001; Sanger and Stoiber, 2001), and their energy content affects the total energy content value of the body. In all the species analysed in this study the energy content $(\mathrm{kJ} / \mathrm{g})$ of the axial muscle had similar values except for $D$. eleginoides, which reached a significantly higher value (Fig. 5A). Gonads of $D$. eleginoides had the lowest energetic content but differences from other species were not significant. It is noticeable that the average values of the energy content $(\mathrm{kJ} / \mathrm{g}$ ) of gonads (Fig. 5B) were not different between the species studied in spite of the diverse degree of sexual maturation.

Energetic values of liver in $G$. gibberifrons showed a great dispersion (Fig. 5C) that could probably be explained by the different origin of fishes. G. gibberifrons caught off Elephant Island (Station E1, Fig. 6) had significantly lower values of liver energy content and higher GSI and bigger yolky oocytes than the females caught off South Georgia (Station B2).

These results support the function of liver as an energy reservoir before the gonadal maturation starts, because the energy content of the liver is higher than $30 \mathrm{~kJ} / \mathrm{g}$, suggesting a high percentage of lipid content (Lucas, 1996). A similar variation in relation with the reproductive cycle was found in the liver of other notothenioid fish ( $N$. coriiceps and $L$. nudifrons, Kamler et al., 2001).
D. eleginoides showed the highest values of energy density ( $7.8 \mathrm{~kJ} / \mathrm{g}$ wet mass, Table 2$)$, probably due to the high lipid content of this species (Eastman, 1993). The rest of the species studied varied between 4.55 and $5.40 \mathrm{~kJ} / \mathrm{g}$.

The energy density (ED) of notothenioids (Table 2) is higher than the values reported for Pleuronectes asper (3.5 to $4.5 \mathrm{~kJ} / \mathrm{g}$ wet mass; Paul, 1997) but equivalent to or slightly lower than the energy values of sexually mature Clupea pallasii (8-10 $\mathrm{kJ} / \mathrm{g}$; Paul et al., 1998). These results stress the important role played by notothenioids in energy transfer in Southern Ocean food webs.

The highest total energy content (TEC) found in this study (Table 2) for a standardised fish of $40 \mathrm{~cm}$ TL corresponds to L. kempi $(7253 \mathrm{~kJ})$, although the $\mathrm{ED}(5.4 \mathrm{~kJ} / \mathrm{g})$ of this species was not the highest. This high TEC could be explained by the higher TW/TL relationship that L. kempi has in comparison with the other notothenioids, which have TEC values of 2000 to $4600 \mathrm{~kJ}$ (Table 2). These values are similar to the values reported for Gadus morhua of $45 \mathrm{~cm}$ TL ( 2400 to $4100 \mathrm{~kJ}$; Lambert and Dutil, 1997).

The estimations of total energy density in the species studied (expressed in relation to TL or TW; Table 2) could be useful to quantify the energy transfer in piscivorous predators such as seabirds or marine mammals (Anthony et al., 2000; Cherel y Ridoux, 1992).

\section{ACKNOWLEDGEMENTS}

This study was supported by grants to J. Calvo from the Fundación Antorchas (Project 13817/4), U.N.P.S.J.B. (HCS No 281/00) and CONICET (PIP 02944). We are grateful to Dr. D. A. Fernández and G. Lovrich for their collaboration in the English revision.

\section{REFERENCES}

Anthony, J.A., D.D. Roby and K.R. Turco. - 2000. Lipid content and energy density of forage fishes from the northern Gulf of Alaska. J. Exp. Mar. Biol. Ecol., 248: 53-78.

Arntz, W.A. and T. Brey. - 2003. - Expedition ANTARKTIS XIX/5 (LAMPOS) of RV "Polarstern" in 2002. Rep. Polar Mar. Res., 462: $1-122$

Bargelloni, L., L. Zane, N. Derome, G. Lecointre and T. Patarnello. - 2000. Molecular zoogeography of Antarctic euphausiids and notothenioids: from species phylogenies to intraspecific patterns of genetic variation. Antarct. Sci., 12: 259-268.

Brickle, P., V. Laptikhovsky and A. Arkhipkin. - 2005. Reproductive strategy of a primitive temperate notothenioid Eleginops maclovinus. J. Fish Biol., 66: 1044-1059.

Calow, P. - 1985. Adaptive aspect of energy allocation. In: P. Tyler 
and P. Calow (eds.), Fish energetics. New perspectives, pp. 1331. Croom Helm, London.

Calvo, J., E. Morriconi, G. Rae and N. San Román. - 1992. Evidence of protandry in a sub-Antarctic nototheniid Eleginops maclovinus (Cuv. and Val. 1830) from the Beagle Channel, Argentine. J. Fish Biol., 40: 157-162.

Calvo, J., E. Morriconi and G. Rae. - 1999. Reproductive biology of the Subantarctic icefish Champsocephalus esox Günther, 1861 (Channichthyidae). Antarct. Sci., 11: 140-149.

Chekunova, V.I. and A.G. Naumov. - 1982. Energy metabolism and food requirements of the Marbled Notothenia, Notothenia rossi marmorata ( Nototheniidae) J. Ichthyol., 22: 112-121.

Cherel, Y. and V. Ridoux. - 1992. Prey species and nutritive value of food fed during summer to King penguin Aptenodytes patagonica chicks at Possession Island, Crozet Archipelago. IBIS, 134: 118-127.

Christiansen, S.J., S.E. Fevolden, O.V. Karamuschko and L.I. Karamuschko. - 1998. Maternal output in polar fish reproduction. In: G. Di Prisco, E. Pisano and A. Clarke (ed.), Fishes of Antarctica. A biological overview. Part I Ecology. pp. 41-51. Springer-Verlag Italy. Milano.

Clarke, A. and I.A. Johnston. - 1996. Evolution and adaptive radiation of Antarctic fishes. Trends Ecol. Evol., 11: 212-218.

Daniels, R.A. - 1978. Nesting behaviour of Harpagifer bispinis in Arthur Harbour Antartic Peninsula. J. Fish Biol., 12: 465-474.

De Witt, H.H., P.C. Heemstra and O. Gon. - 1990. Nototheniidae. Notothens. In: O. Gon and P.C. Heemstra (ed.), Fishes of the Southern Ocean. pp. 25-40. J.L.B. Smith Institut of Ichthyology. Grahamstown, South Africa.

Duhamel, G., K.H. Kock, E. Balguerías and J.C. Hureau. - 1993. Reproduction in fish of the Weddell Sea. Polar Biol., 13: 193-200.

Eastman, J. - 1993. Antarctic fish biology, evolution in a unique environment. Academic Press Inc., San Diego.

Eastman, J.T. - 1995. The evolution of Antarctic fishes: Questions for consideration and avenues for research. Cybium, 19: 371-389.

Eastman, J.T. and A.L. DeVries. - 2000. Aspects of body size and gonadal histology in the Antarctic toothfish, Dissostichus mawsoni, from McMurdo Sound, Antarctica. Polar Biol., 23: 189-195.

Eastman, J.T. and R.R. Eakin. - 2000. An updated species list for notothenioid fish (Perciformes; Nototheniodei), with comments on Antarctic species. Arch. Fish. Mar. Res., 48: 11-20.

Eastman, J.T. and A.R. McCune. - 2000. Fishes on the Antarctic continental shelf: evolution of a marine species flock?. J. Fish Biol., 57: 84-102.

Ekau, W. - 1991. Reproduction in high Antarctic fishes (Notothenioidei). Meeresforsch, 33: 159-167.

Everson, I., K.H. Kock, S. Campbell, G. Parkes, D. Cielniaszek and J. Szlakowski. - 1991. Reproduction in the mackerel icefish (Champsocephalus gunnari) at South Georgia. Document WGFSA-91/7. CCAMLR Science. Hobart, Australia: $12 \mathrm{pp}$.

Everson, I. - 1994. Timescale of ovarian maturation in Notothenia coriiceps; evidence for a prolongated adolescent phase. J. Fish Biol., 44: 997-1004.

Everson, I., K.H. Kock and G. Parkes. - 1996. Ovarian development associated with first maturity in three Antarctic channichthyid species. J. Fish. Biol., 49: 1019-1026.

Everson, I., K.H. Kock, S. Campbell, G. Parkes, Z. Cielniaszek and J. Szlakowsky. - 2000. Reproduction in the mackerel icefish, Champsocephalus gunnari, at South Georgia. CCAMLR Science, 7: 1-12.

Everson, I. and A. Murray. - 1999. Size at sexual maturity of Patagonian toothfish (Dissostichus eleginoides). CCAMLR Science, 6: $37-46$.

Fischer, W. and J.C. Hureau (eds.). - 1985. FAO Species identification sheets for fishery purposes. Southern Ocean (fishing areas 48, 58 and 88). (CCAMLR convention area). Food and Agriculture Organization of the United Nations, Rome. Vols. 1 and 2: pp. 471 .

Friedrich, C. and W. Hagen. - 1994. Lipid content of species of notothenioid fish from high Antarctic waters and ecological implications. Polar Biol., 14: 359-369.

Hagen W., G. Kattner and C. Friedrich. - 2000. The lipid compositions of high - Antarctic nototheniod fish species with different life strategies. Polar Biol., 23 : 785-791.

Hunter, R.J. and B.J. Macewicz. - 1985. Rates of atresia in the ovary of captive and wild northern anchovy Engraulis mordax. Fish. Bull., 83: 119-136.
Johnston I.A. - 2001. Genetic and environmental determinants of muscle growth patterns. In: I.A. Johnston (ed.). Muscle development and growth, pp. 141-186. Fish Physiology Series, Vol. 18. Academic Press.

Johnston, I.A. and J. Battram. - 1993. Feeding energetics and metabolism in demersal fish species from Antarctic, temperate and tropical environments. Mar. Biol., 115: 7 -14.

Kamler, E., B. Krasicka and S. Rakusa-Suszczewski. - 2001. Comparison of lipid content and fatty acid composition in muscle and liver of two notothenioid fishes from Admiralty Bay (Antarctica): an ecophysiological perspective. Polar Biol., 24: 735-743.

Kock, K.H. - 1989. Reproduction in fish around Elephant Island. Arch. FischWiss., 39: 171-210.

Kock, K.H. - 1992. Antarctic Fish and Fisheries. Cambridge University Press, Great Britain.

Kock, K.H. and I. Everson. - 1997. Biology and ecology of mackerel icefish, Champsocephalus gunnari: an Antarctic fish lacking haemoglobin. Comp. Biochem. Phys., 118 A: 1067-1077.

Kock, K.H. and A. Kellermann. - 1991. Reproduction in Antarctic notothenioid fish. Antarct. Sci., 3: 125-150.

Kock, K.H. and C. Stransky. - 2000. The composition of the coastal fish fauna around Elephant Island (South Shetland Islands, Antarctica) Polar Biol., 23: 825-832.

Kock, K.H. and S. Wilhelms. - 2003. The reproductive state of Antarctic fish in the Elephant Island - South Shetland Islands region in March-April 2003. Bundesforschungsanstalt für Fischerei, Institut für Seefischerei: 1-4.

Kock, K.H., C. Jones and S. Wilhelms. - 2000. Biological characteristics of Antarctic fish stocks in the southern Scotia Arc region. CCAMLR Science, 7: 1-42.

Kozlov, A.N. - 1981. Relationship between intensity and periods of protein increase and fat accumulation in the marbled Notothenia, Notothenia rossii marmorata (Nototheniidae). J. Ichthyol., 21: 91-102. Fide: C. Friedrich and W. Hagen. - 1994. Lipid content of species of notothenioid fish from high Antarctic waters and ecological implications. Polar Biol., 14: 359-369.

Kozlov, A.N. - 1982. Seasonal dynamics of the morphophysiological and biochemical indices of Notothenia gibberifrons. J. Ichthyol. 22:108-112. Fide: C. Friedrich and W. Hagen. - 1994. Lipid content of species of notothenioid fish from high Antarctic waters and ecological implications. Polar Biol., 14: 359-369.

Lambert, Y. and J.D. Dutil. - 1997. Condition and energy reserves of Atlantic cod (Gadus morhua) during the collapse of the northern Gulf of St. Lawrence stock. Can. J. Fish. Aquat. Sci., 54: 2388-2400.

La Mesa, M., V. Caputo, R. Rampa and M. Vacchi. - 2003. Macroscopic and histological analyses of gonads during the spawning season of Chionodraco hamatus (Pisces, Channichthyidae) off Terra Nova Bay, Ross Sea, Southern Ocean. Polar Biol., 26: 621-628.

Lucas, A. - 1996. Bioenergetics of aquatic animals. Taylor and Francis, London.

Macchi, G.J. and E. Barrera-Oro. - 1995. Histological study on the ovarian development of mackerel icefish (Champsocephalus gunnari) from the South Georgia Islands. CCAMLR Science, 2: $35-49$.

McEvoy, I. and J. McEvoy. - 1992. Multiple spawning in several commercial fish species and its consequences for fisheries management, cultivation and experimentation. J. Fish Biol., 41: 125-136.

Montgomery, J. and K. Clements. - 2000. Disaptation and recovery in the evolution of Antarctic fishes. Tree, 15: 267-271.

North, A.W. and M.C. White. - 1987. Reproductive strategies of Antarctic fish. In Proc. V Congr. Europ. Ichthyol. Stockolm. 1985. Ed. S.O. Kullander and Fernholm, pp 381-390.

Panozo, R.G. - 1996. Evidencia de hermafroditismo secuencial en el robalo Eleginops maclovinus Valenciennes, 1830 (Perciformes-Eleginopsidae), pp. 1-44. PhD thesis, Departamento de Oceanografia de la Universidad de Concepcion, Chile.

Paul, A.J. - 1997. The use of bioenergetic measurements to estimate prey consumption, nutritional status and thermal habitat requirements for marine organisms reared in the sea. Bull. Natl. Res. Inst. Aquacult., Suppl., 3: 59-68.

Paul, A.J., J.M. Paul and E.D. Brown. - 1998. Fall and spring somatic energy content for Alaskan Pacific herring (Clupea pallasii Valenciennes, 1847) relative to age, size and sex. $J$. Exp. Mar. Biol. Ecol., 223: 133-142. 
Permitin, Y.Y. - 1973. Fecundity and reproductive biology of icefish (Channichthyidae), fish of the family Muraenolepidae and dragonfish (Bathydraconidae) of the Scotia Sea (Antarctica). J. Ichthyol., 13: 204-215.

Rae, G.A. and J. Calvo. - 1995. Fecundity and reproductive habits in Patagonotothen tessellata (Richardson, 1845) (Pisces, Nototheniidae) from the Beagle Channel, Argentine. Antarct. Sci., 7: 235-240.

Rae, G.A. and J. Calvo. - 1996. Histological analysis of gonadal development in Patagonotothen tesellata (Richardson 1845) (Nototheniidae: Pisces) from the Beagle Channel, Argentina. $J$. Appl. Ichthyiol., 12: 31-38.

Russo, A., F. Angelini, R. Carotenuto, F.M. Guarino, C. Falugi and C. Campanella. - 2000. Espermatogenesis in some Antarctic teleosts from the Ross Sea: histological organisation of the testis and localisation of bFGF. Polar Biol., 23: 279-287.

Sanger A.M. and W. Stoiber. - 2001. Muscle fiber diversity and plasticity. In: I.A. Johnston (ed.) Muscle development and growth, pp. 187-250. Fish Physiology Series, Vol. 18. Academic Press.

Schneppenheim, R., K.H. Kock, G. Duhamel and G. Janssen. -
1994. On the taxonomy of the Lepidonotothen squamifrons group (Pisces, Perciformes, Notothenioidei). Arch. Fish. Mar. Res. 42: 137-148.

Shandikov, G.A. and T.I. Faleeva. - 1992. Features of gametogenesis and sexual cycles of six notothenioid fishes from East Antarctica. Polar Biol., 11: 615-621.

Stankovic, A., K. Spalik, E. Kamler, P. Borsuk and P. Weglenski. 2002. Recent origin of sub-Antarctic notothenioids. Polar Biol., 25: 203-205

Van der Molen, S. and J. Matallanas. - 2003. Oocyte development and maturity classification of Gerlachea australis from the Weddell Sea, Antarctica. Polar Biol., 26: 653-658.

White, M.G. and P.J. Burren. - 1992. Reproduction and larval growth of Harpagifer antarcticus Nybelin (Pisces, Notothenioidei). Antarct. Sci., 4: 421-430.

Yoneda, M., K. Futagawa, M. Tokimura, H. Horikawa, S. Matsuura and M. Matsuyama. - 2002. Reproductive cycle, spawning frequency and batch fecundity of the female whitefin jack Kaiwarinus equula in the East China Sea. Fish. Res., 57: 297-309. 